\title{
Çağdaş Heykel Sanatında Malzemeye Dayalı Yeni Bir Kopyalama Önerisi: Oasis
}

\section{A New Proposal for a Material Based Reproduction in Contemporary Sculpture: Oasis}

\section{Döndü Tülay Özkul}

Arş. Gör. Dr. Ankara Hacı Bayram Veli Üniversitesi Güzel Sanatlar Fakültesi Heykel Bölümü email: dtulay_durmus@hotmail.com (DORCID ID: https://orcid.org/0000-0003-2789-5396

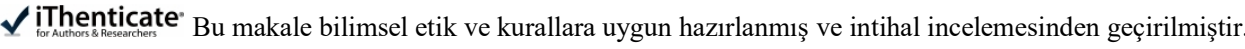

Atıf (APA 6)/Tocitethisarticle

Özkul, D. T. (2020). Çağdaş heykel sanatında malzemeye dayalı yeni bir kopyalama önerisi: Oasis. Atatürk Üniversitesi Güzel Sanatlar Enstitüsü Dergisi, 26(44), 90-103. doi: https://doi.org/10.35247/ataunigsed.682336

Makale Gönderim Tarihi/Received: 30/01/2020

Makale Kabul Tarihi/Accepted:13/03/2020

Makale Yayın Tarihi/Published:19/03/2020

Research Article / Araștırma Makalesi

\section{Özet}

$\mathrm{Bu}$ araștırmanın amacı heykel sanatında bir yöntem olarak kullanılan kalıp alma ve kopya etme tekniklerine yeni bir önerme sunmaktır. Günümüz heykel sanatında çoğaltma yöntemleri geleneksel anlamda, modelaj yapma, kalıp alma ve son olarak alınan kalıbın döküm işlemlerini içeren bir sırayı takip etmektedir. Bunun yanı sıra hazır nesnelerden de kalıp alınarak çoğaltma işlemi gerçekleştirilebilmektedir. $\mathrm{Bu}$ işlemler sırasında heykeltıraş orijinal eserin kopyasını modellerken gerçek nesne ile kopyası arasında sanatçının kontrolü dışında malzemenin özelliklerine bağlı olarak farklılıklar oluşmasına neden olabilmektedir. Bu araştırma kapsamında, geleneksel kopyalama yöntemlerinin dışında yer alan, çiçek süngeri olarak bilinen "Oasis"in kalıp olarak kullanılması üzerine bir deneme gerçekleștirilmiștir. Yapılan araştırmalar sonucunda Oasis'in maddesel özelliklerinden faydalanılarak çeşitli nesnelerin kalıpları olussturularak bir kopyalama yöntemine deneysel olarak gidilmiştir. $\mathrm{Bu}$ kopyalama neticesinde elde edilen bulgular görseller üzerinden teknik çözümlemeleri yapılarak, malzemenin olumlu ve olumsuz yönleri bir rapora dönüştürülmüștür. Kolay şekillendirilebilen bu malzeme ile nesne çoğaltımına, zamandan ve emekten tasarruf etmek adına sanatçllara yeni bir üretme önerisi sunarak alana katkı sağlaması amaçlanmaktadır. Bu çalışma, belli ölçekler ile sınırlandırılan iki ve üç boyutlu nesneler üzerinden ampirik yöntem ile temellendirilerek elde edilen bulguların rapor haline getirilmesini kapsamaktadır.

Anahtar Kelimeler: Heykel, Malzeme, Çoğaltma teknikleri, Kopya, Kalıp

\begin{abstract}
The aim of this research is to propose a new method of molding and casting sculpture techniques. In current sculpture practice, conventional methods of reproduction follow a sequence that includes modeling, molding and finally casting. In addition, taking molds from ready-made objects and reproduction of these objects is also possible. Within this process, the material qualities of the medium generates differences between the original and the copy beyond the control of the artist. In this regard, an experiment was carried out on the sculptural use of "Oasis"- the flower sponge- an unconventional method of reproduction, depending on its material qualities. In order to save time and effort in mass production techniques or to reproduce three-dimensional objects, the method provides artists with a new production technique. This study covers the reporting of findings based on experiments with two and three dimensional objects limited by certain scales, based on empirical studies
\end{abstract}

Keywords: Sculpture, Material, Replica techniques, Copy, Mold

\section{Giris}

Türk Dil Kurumunun resmi web sitesinde kopyalamak fiili "Aynısını veya benzerini çoğaltmak" şeklinde açıklanmaktadır (“Türk Dil Kurumu”, t.y.). Kelime kökenine bakıldığında kopya, Fransızca copie yani "çoğaltma, nüsha" sözcüğünü karşılarken, Fransızca sözcük Latince copia "bolluk" sözcügünnden türemiştir ("Kopya kelime kökeni”, t.y.). Kopyalama fiili hem sözlük anlamında hem de kelime kökenine bakıldığında çoğalma/ üreme sözcüklerini karşılamaktadır. Lippold'a göre kopya "Bir eserin orijinal bütünlüğü ve tek tek hatlarıyla yeniden üretilmesi gereken taklididir" (Bulat, M., Bulat, S., Sabahat, Aydın, 2014, s. 69). Bu bağlamda kopya eser, ana hatları, biçim ve son olarak oran açısından orijinal eserin taklit edilmesi şeklinde açıklanabilir.

Antik dönemlerden günümüze dek farklı nedenler ile birçok eserin kopyalanmasına ihtiyaç duyulmuştur. Örneğin, Roma imparatorluğunun Akdeniz kentlerine düzenlediği seferler ile Roma'ya getirilen birçok Yunan heykeli kent meydanlarında sergilenmiştir. Yunan heykeline gösterilen yoğun ilgi, koleksiyonerliğin doğmasına neden olurken, meydana gelen talep karşısında da kopyacılığın ortaya çıkmasında önemli bir rol üstlenmiştir (Turak, 2017, s.138). Bir başka neden ise Rönesans çağında antika heykellere karşı duyulan yüksek ilgi zamanla, bu heykellerin sarayların bir dekoru haline dönüşmesine neden olmuştur (“Original sculptures”, 2009). Görüldüğü üzere kopya 
eserler tarih boyunca popülerliğini çeşitli sebepler ile korumaya devam ederken, heykellere olan yoğun talebi karşılamak için heykeltıraşlar, çeşitli kopyalama teknikleri geliştirip kullanmışlardır. Antik Çağ'da kopyalama işlemleri genellikle noktalama makinesi, üç bacaklı pergel, ahşap çerçeve ve şakül ile ölçerek, kaliper (ölçüm pergeli) ya da ahşap çerçeve metodu yardımıyla gerçekleştirilmiştir.

\subsection{Noktalama makinesi ile kopyalama yöntemi}

M.Ö. 1. yüzyılda heykeltıraş Pasiteles tarafından kullanıldığı düşünülen (Yılmaz, 2018, s. 29) noktalama makinesi ile yapılan kopyalama işleminde (Görsel 1) heykeltıraş tarafından hem modelde hem de kopyalama işleminin yapılacağı malzeme üzerinde belirlenen 3 referans noktası merkeze alınarak ölçüm noktaları saptanmaktadır. Bu referans noktaları yükseklik, en ve genişliğin birebir ölçüde belirlemek için kullanılarak elde edilen ölçüm ile sabitlenen noktalar üzerinden yontma işlemi gerçekleştirilmektedir.

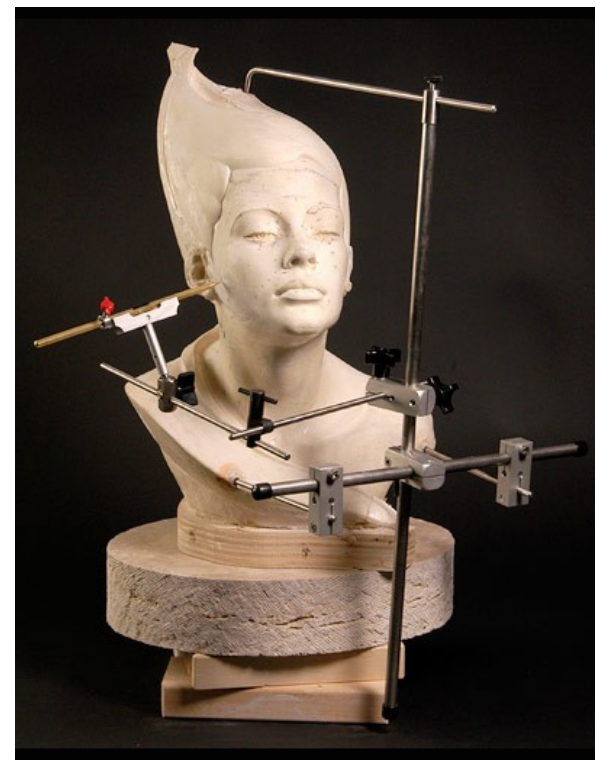

Görsel 1. Noktalama aleti

Noktalama yöntemi büyütülerek ya da küçülterek üretilmek istenen kopya heykel üretiminde kullanılmamaktadır ("Pointing machine", t.y.). Bunun yanı sıra noktalama yönteminde kontrol mekanizması merkez alındığı için hata yapma riski en aza indirgenmektedir.

\section{2. Üç Bacaklı pergel ile kopyalama yöntemi}

Üç bacaklı pergel (Görsel 2) ile kopyalama işleminin yapılacağı model üzerinde orta noktasında yer alan sivri uç sayesinde sabitlenerek hareket eden iki kolu yardımıyla belirlenen yerden iki noktayı ölçerek çalışılacak malzeme üzerine belirlenen iki noktaya aktarmayı sağlamaktadır.

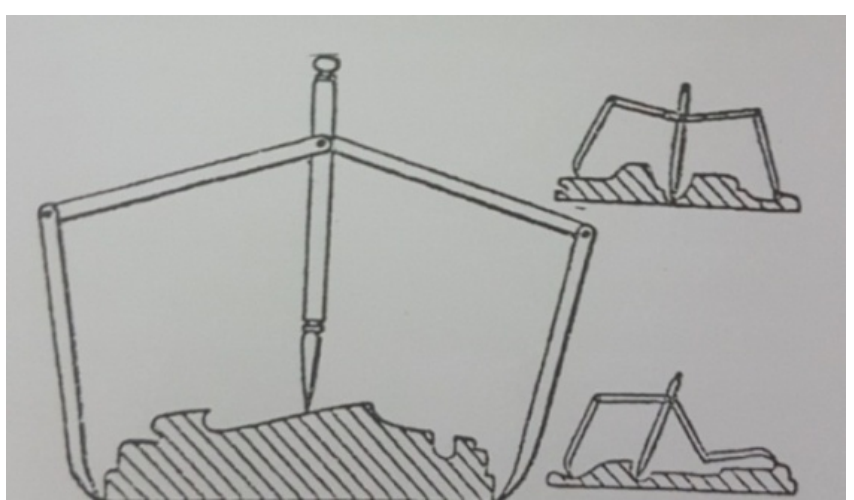

Görsel 2. Değişik noktalama yerlerini işaretleyebilmek için ayaklı pergelin kullanım (Alex Miller)

Ancak modelin üzerinde A ve B noktalarından sabitlenerek alınan ölçümler, yontulacak malzemenin üzerine $C$ ve D noktalarına kurşun kalem ile işaretlendikten sonra noktalar arasında yer alan kavis ve yükseklik ölçümleri deneme ve yanılma metodu ile aktarılmaktadır (Bulat, 1999, s. 128). Bu bağlamda ayaklı pergel yöntemi ile kopyalama yaparken hata yapma riskinin daha yüksek olduğu anlaşılmaktadır. 


\subsection{Ahşap Çerçeve Metodu ile Kopyalama Yöntemi}

Ahşap çerçeve metodu ile kopyalama yönteminde, kopyalama işleminin gerçekleşeceği modelin ve kopyanın gerçekleştirileceği malzemenin üzerinde yer alan ahşap çerçevenin (Görsel 3) boyutlarının aynı olması gerekmektedir.

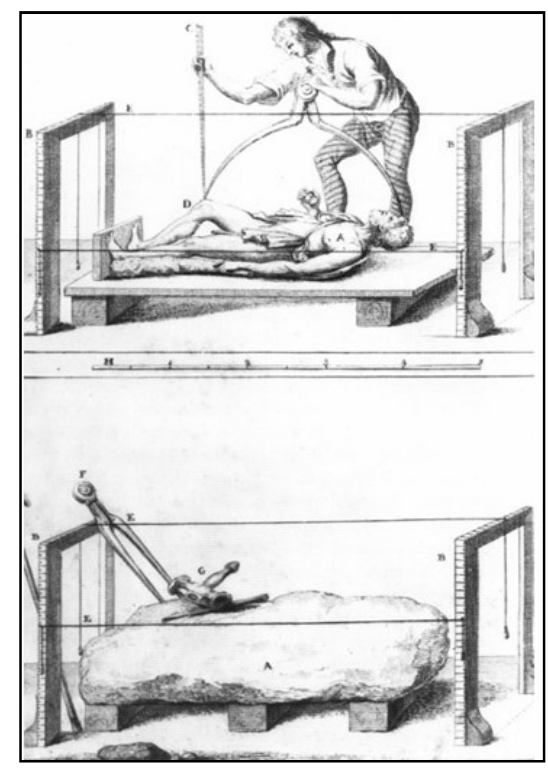

Görsel 3. Ahşap çerçeve metodu ile kopyalama yöntemi

$\mathrm{Bu}$ kopyalama yönteminde kopyalanacak modelden ölçü alınırken, ölçüm çubuğu belirlenen noktaya konumlandırılarak çerçeve üzerinde T cetveli ve ölçüm çubuğu üzerinde yer alan sayılar kayıt edilerek kopyanın gerçekleştirileceği malzeme üzerinde yer alan çerçevede aynı ölçülere ulaşana kadar yontma işlemi gerçekleştirilmektedir (Bulat, 1999, s. 129).

\subsection{Ahşap Çerçeve ve Şakül ile Kopyalama Yöntemi}

Ahşap çerçeve ve şakül ile kopyalama yönteminde hem kopyalanacak model hem de kopya işleminin yapılacağı malzeme, modeli dıştan dışa kapsayacak şekilde ölçülendirilerek, birbirine eşit olarak kesilerek derecelendirilen iki ahşap çerçeve (Görsel 4) kullanılmaktadır. Bu çerçevelere üstten yerleştirilen şaküller aracılığ́ ile ölçü alınmaktadır.

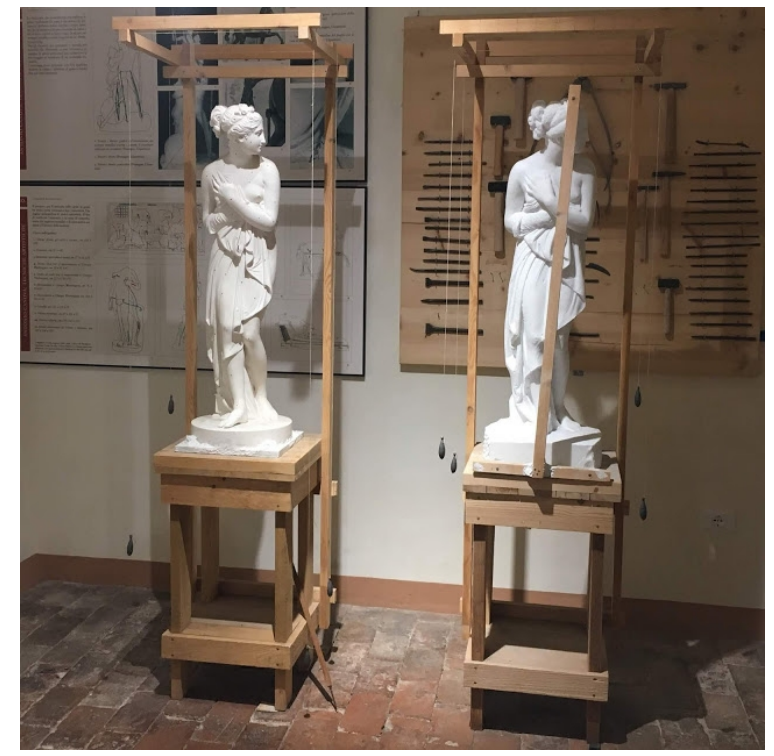

Görsel 4. Ahşap çerçeve ve şakülle heykel üzerinde ölçümleme yapma işlemi

Aynı zamanda ahşap çerçevenin üzerine sağa sola, yukarı ve aşağıya hareket edip, sabitlenebilen bir mekanizma takılmaktadır. Bu mekanizma sayesinde içe ve dışa hareket edilen ölçü çubuğu ile modelden ölçü alınarak " $T$ " 
parçasının tümü kopyalanacak malzemenin üzerine aktarılabilmektedir. Model üzerinde çerçeveye aktarılan yeni koordinatlara ulaşıncaya kadar yontma işlemi devam etmektedir (Bulat ve diğerleri, 2014, s. 88).

\subsection{Kaliper (Ölçüm Pergeli) ile Kopyalama Yöntemi}

Kaliper yay şeklindeki kolları ile belirlenen ölçüyü başka bir yere taşımaya yaramaktadır. Kaliper ile kopyalanacak model ve yontulacak malzeme üzerinde belirlenen üç sabit nokta üzerine (Görsel 5) aktarılarak yarım daireler çizilmektedir. Temel olarak çizilen yarım dairelerin kesişme noktaları sıfırlanana kadar malzeme dıştan içe doğru yontulmaktadir.

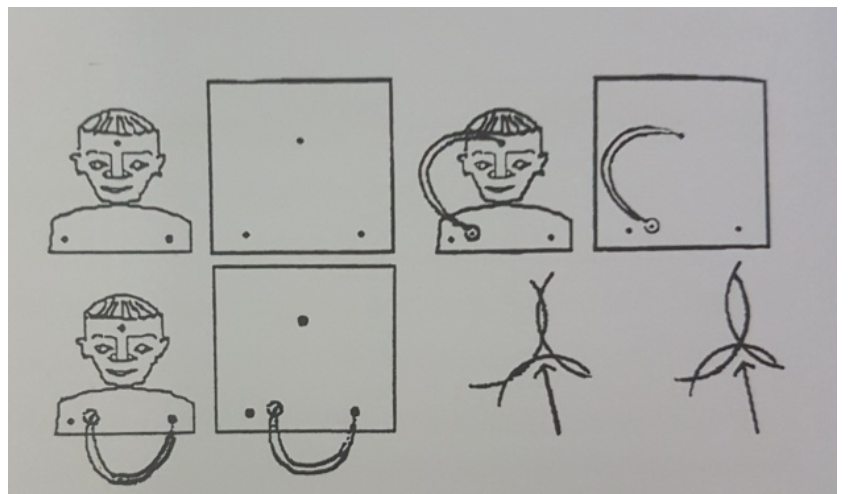

Görsel 5. Kaliper aleti ile modelden taş blok üzerine ölçümleme

Antik Çağ döneminde heykeltıraşlar bu yöntemler ile kopyalama işlemini gerçeğe en yakın şekilde aktarmışlardır. Ancak antik dönem kopya ve orijinal eser arasında kopyalama tekniğine bağlı olarak farklar ortaya çıkmaktadır. Çünkü kopyalama teknikleri, her bir sanatçının kendi döneminin izlerini taşımaktadır. Orijinal ve kopya eser, kopyalama işlemi sırasında kullanılan malzeme, araç ve aletler, kopyalandığ 1 dönemin teknolojisi ile doğrudan orantılı olduğu için kopya ve orijinal eser arasındaki benzerlik ilişkisi dönemler arasında farklılık göstermektedir. Bu konuda John Boardman, heykelde kopyacılık sektörünün hem tekniğin hem de sanatçıların yeteneği ölçüsünde aslına sadık olduğunu ileri sürmektedir (Boardman, 2013, s. 16).

M.Ö. IV yüzyılda yapılmış olan (Görsel 6) Olympia Zeus alınlığına ait aslan başlarının Roma döneminde yapılan kopyası (Görsel 7), Carl Blümel tarafından iyi bir taklit olarak nitelendirilmiştir (Bulat ve diğerleri, 2014, s. 70). Aslan başının Roma dönemi kopyası incelendiğinde ana hatları, biçim, oran ve ayrıntı açısından orijinali ile arasında çeşitli farklar olduğu gözlemlenmektedir. Bu farklılıklar arasında ilk olarak iki yontucunun artistik stilleri göze çarpmaktadır. Aynı zamanda her iki aslan başının hem konumlandırma hem de fotoğrafların çekim açısı farklı olduğu için tüm detaylar hakkında yorum yapmak zordur. Ancak görsellerde yer alan aslanların yelelerine dikkatlice bakıldığında, detaylandırmanın kopya eserde orijinal esere oranla daha yüzeysel kaldığı görülmektedir. Son olarak orijinal heykelde yer alan planların geçişlerindeki sertliğin, kopya heykelde daha yumuşak ele alındığ fark edilmektedir.

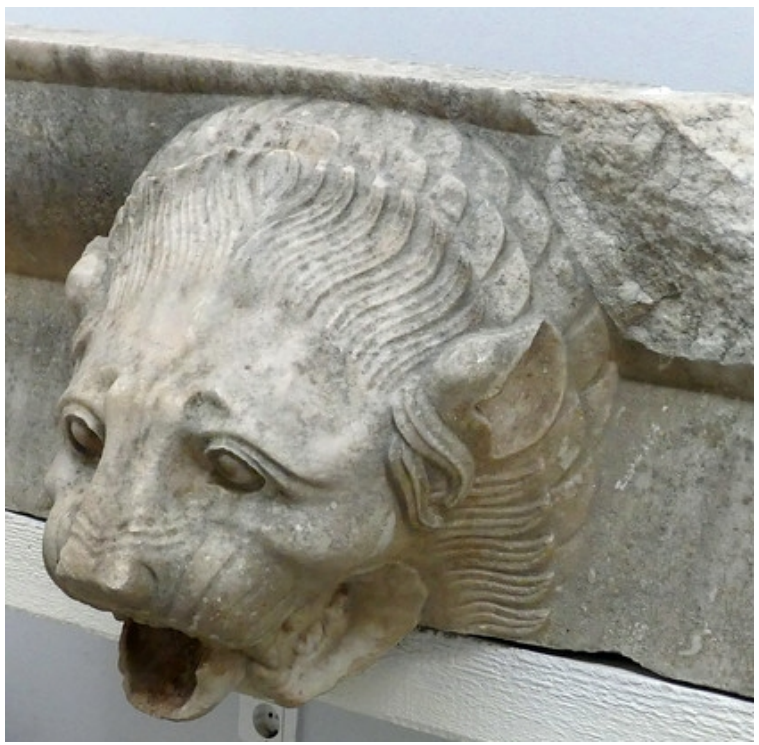

Görsel 6. Olympia Zeus Tapınağında bulunan Aslan Başı Berlin Bergama Müzesi, İ.Ö.460 


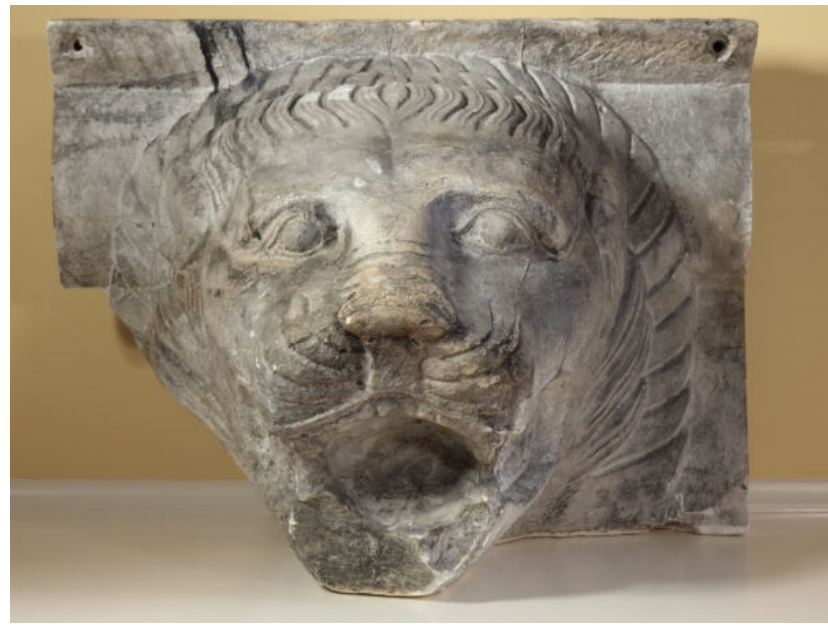

Görsel 7. Olympia Zeus Tapınağında bulunan Aslan Başı Roma Dönemi kopyası, Berlin Bergama Müzesi

Burada gerçekçiliği tasvir edilen Aslan Başı ister istemez kendinden sonraki her taklidi ile tekrar dolaşıma girerek kendi gerçeğinin altını çizer. Böylece yapılan her taklidi ile Aslan Başı, kendi gerçekliğini oluşturarak bir sonraki taklidinin aslı olarak yaşamaya devam eder (Çelik, 2019, s. 34).

Geçmişte olduğu gibi olsa günümüzde varlığını kısmen de devam ettiren kopyalama yöntemleri yerini yeni yöntemlere bırakarak, geçmiş zamanda olduğu gibi bugün de merkezi bir rol üstlenmeye devam etmektedirler. 20. yüzyılda, bilim ve teknoloji alanlarında yaşanan hızlı değişimler ile gelişen yeni üretim teknikleri karşısında gerek sanatçı gerekse heykel yeniden biçimlenir (Özkul, 2019, s. 78). Bu yüzyılda, alternatif malzemeler aracılığıyla teknoloji merkezleri ve sanatçılar arasında sağlanan işbirlikleri sayesinde yeni bir dilin oluşması sağlanır (Bulat, 2014, s. 63). Oluşan bu yeni dilde 20. yüzyıla kadar manuel olarak yapılan birçok iş kolunda, insanların yerini zamanla makineler almaya başlar. 21. yüzyıla gelindiğinde ise üretilen robotlar ağır ve emek istenen işleri yürütecek konuma gelir (Atmaca'dan aktaran İba, 2018).

Antik Çağ'da çeşitli ölçümleme aletleri kullanılarak gelenekselleşen kopyalama yöntemlerine karşın günümüz teknolojisinde bilgisayar programları aracılığı ile kusursuz kopyalama işlemleri gerçekleştirilmektedir. Küçük ebatlarda iki ya da üç boyutlu nesnelerin üretilmesi ve çoğaltılması için 3D tarama (Görsel 8), uygulama, bask1 ve modelleme merkezlerinin yanı sıra büyük ölçekli üretimler için CNC (Computer Numeric Control) makineleri (Görsel 9) yaygın biçimde kullanılmaktadır.

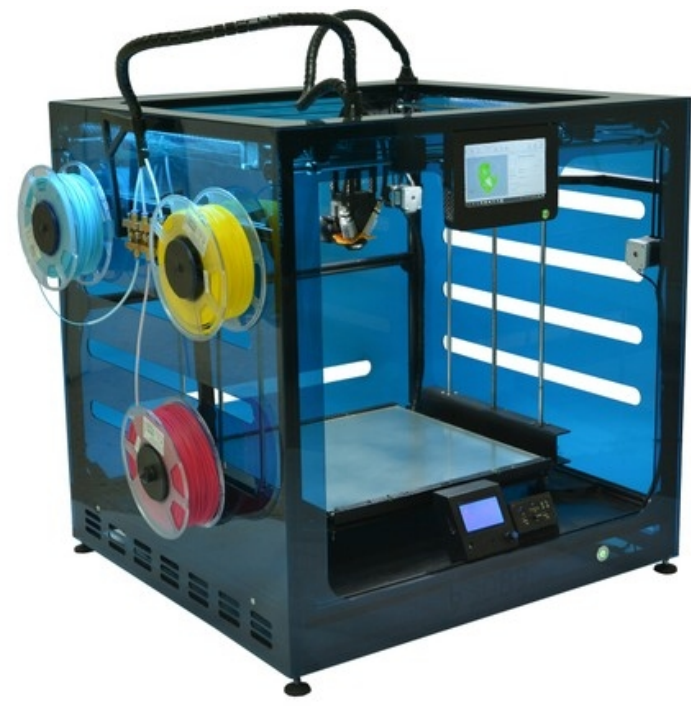

Görsel 8. 3 Boyutlu Yazıcı

Her geçen gün kullanım alanları giderek artan üç boyutlu yazıcılar, endüstri, mimari, tıp ve sanat gibi birçok alanda kullanılmaktadır (Poyraz ve Dolunay, 2014, s. 69). Günümüzde heykel sanatçıları Otocad, 3Ds Max, Alias Maya, Zbrush, Mudbox gibi yazılımlar aracılığı ile bilgisayar destekli tasarımlar yaparak üç boyutlu yazıcıları sanatsal amaçlar için kullanmaktadırlar (Sağlamtimur, 2010, s. 222-223). Teknolojide yaşanan değişim belirli alanlarda sıklıkla kullanılmakta ancak bireysel üretimlerde pahalı olduğu için çoğu zaman tercih edilmemektedir. 


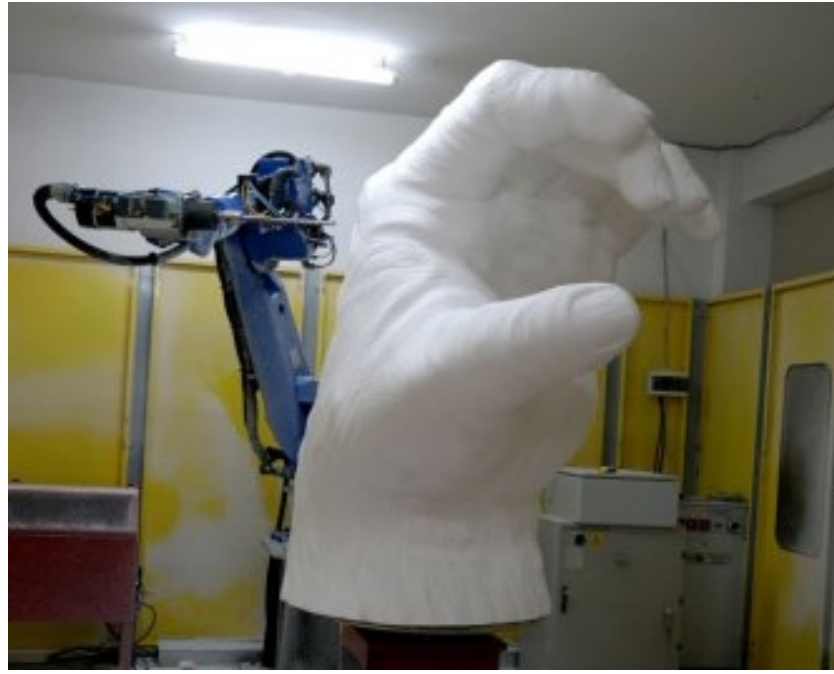

Görsel 9. Cnc Makinesi

Bu sebeple araştırmada, iki ve üç boyutlu nesneyi kopyalama konusunda geleneksel metotların dışında alternatif bir malzeme önerilerek sanatçının özgürlük alanını genişletmek amaçlanmaktadır. Yeni teknik ve açılımlar ile sanat alanında kullanılan malzeme paralel olarak ilerlediğinden, sunulan her yeni öneri sanatta malzeme pratiğinin genişlemesini sağlamaktadır (İşcanoğlu, 2017, s. 51). Sanatta, özellikle heykel sanatında alternatif malzemeler heykel sanatına yeni imkânlar sağlayarak hem kavramsal hem de biçimsel açıdan ifade olanaklarını etkilemektedir (Hiçyılmaz, 2018, s. 2).

Bu bağlamda alana katkı sağlamak için Oasis ile çeşitli denemeler gerçekleştirilmiş ve bulgular raporlaştırılmıştır. Ancak malzemenin yumuşak olması kalıcı olmasına izin vermediğinden iki sene boyunca devam eden çalışmalar süresince çeşitli endüstriyel malzemeler ile sertleşmesi, kalıcı olması sağlanmıştır.

\section{Yöntem}

Bu araştırmada betimsel yöntemin yanı sıra deneysel yöntem de kullanılmıştır. Konu kapsamında geçmişten günümüze kopyalama teknikleri hakkında literatür taraması yapılmış olup aynı zamanda kullanılan malzemenin kullanım amacı doğrultusunda dayanıklılığı tespit edilerek, malzemenin sertliğini, kullanılışını ve verimliliğini arttıracak müdahalelerde bulunulmuştur. Sayısal yöntemlerin kullanılmasından ziyade deneye dayalı, ampirik yöntemler kullanılmıştır

\section{Uygulama}

Aslında çiçek süngeri olarak tanımlanan malzeme, zaman içerisinde halk ve tüketici diline Oasis (Görsel 10) olarak geçmiştir. Aynı zamanda Oasis, İngilizce ve Fransızca' da vaha, çöl ortasında sulak alan, cennet, güvenli korunma yeri veya sığınak anlamlarına gelmektedir (“Oasis çiçek süngeri”, t.y.). Bu nedenledir ki Oasis, genel olarak suyu içinde barındırdığı için canlı çiçeklerin tazeliğini uzun süre koruması ve çiçekleri bir arada tutması amacı ile kullanılan, çiçekçilik sektörünün önde gelen önemli malzemelerinden biridir.

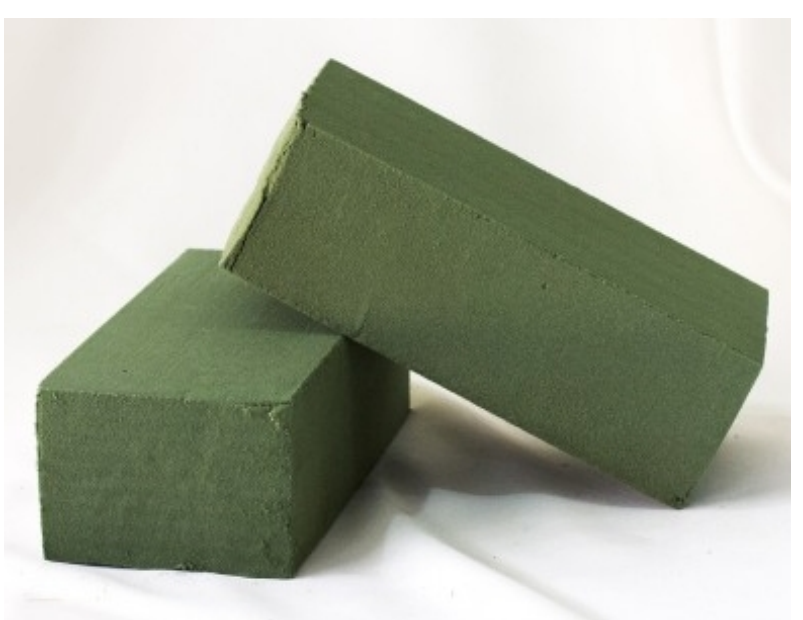

Görsel 10. Oasis (Çiçek süngeri) 
Oasis, kullanım amacı doğrultusunda suyu emip içinde hapsetme özelliğine sahiptir. Bu sebeple de gereğinden fazla hassas, emici ve gözenekli bir yapıya sahiptir. Bu özellikleri ile Oasis, iki ya da üç boyutlu nesne elde edebilmek için hem avantajlı hem de dezavantajlı bir malzemedir. Malzemenin hassasiyeti, kalıbı alınacak nesnenin hacmini kendine olduğu gibi geçirmesi açısından kolaylık sağlayarak onu avantajlı hale getirmektedir. Bu sayede elde edilen negatif kalıp, oldukça pürüzsüz ve hacimsel çıkmaktadır. Malzemenin bu hassasiyeti bir yanı ile avantaj sağlarken, Oasis'in kırılgan ve dayanıksız olan diğer yanı ile kalıp almada gerekli olan şartlar için olumsuzluk oluşturarak dezavantaj sağlamaktadır. Bu sebeple araştırmada, Oasis’i benzersiz hale getiren bu özellikleri kullanım amacı doğrultusunda farklı malzemeler ile yeniden düzenlenerek, kalıp alma eyleminde gerekli olan koşulların yaratılması sağlanmıştır. Burada ilk olarak kalıbı çıkarılmak istenen nesne, sünger yüzeyine herhangi bir malzeme ile müdahale edilmeden bastırılarak, sünger yüzeyinde nesnenin negatif görüntüsü elde edilmektedir. Ardından negatif kalıbın kalıcılığının sağlanması için çeşitli sertleştiriciler kullanılarak yüzeyde elde edilen negatif boşluk sabitlenerek, kalıp almak için uygun hale getirilmektedir.

Benzer bir metodla herhangi bir nesnenin negatif kalıbı elde etme yöntemi endüstriyel üretim sanayisinde de kullanılmaktadır. Bu yöntem M.Ö. 4000 yılından itibaren kullanılmaya başlayan, yüzyıllar içerisinde geliştirilen, heykeltıraşlar tarafından da kullanılan bir döküm tekniğidir. İki parçadan oluşan ahşap/metal kalıbın (Mühendislikte alt ve üst derece olarak adlandırılır) (Görsel 12) içine üretimi yapılmak istenen parça tasarımı yerleştirilir. Ardından modelin üzerine grafit tozu dökülür. İlk olarak karılan (Görsel 11) daha sonra ince elekten (Görsel 13) geçirilen kum ile modelin üzerinde ince bir tabaka oluşturulur.

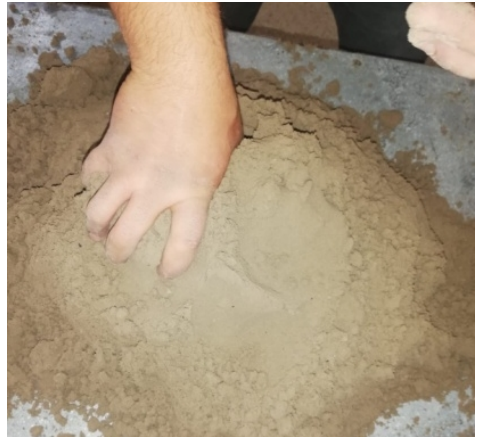

Görsel 11. Kumun karılması

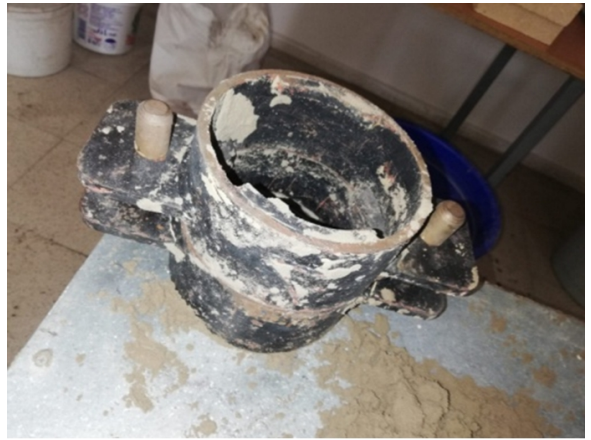

Görsel 12. İki parçadan oluşan kalıp

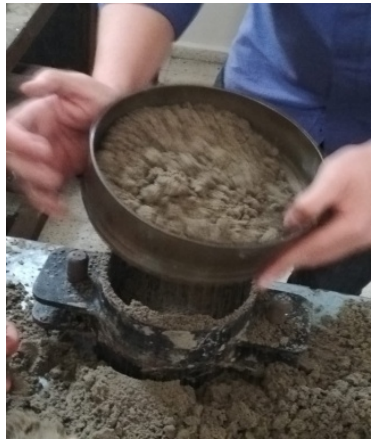

Görsel 13. Kumun elenmesi

Oluşturulan kum tabakası tokmak yardımıyla sıkıştırılarak (Görsel 14), içeride yer alınan modelin kalıbının kuma çıkması sağlanır. Kalıba sıkıştırılan kumun üzerine mastar çekilerek (Görsel 15), düzleşmesi sağlanır. Ardından kalıp ters çevrilerek kalıbı alınmak istenen (Görsel 16), model içinden dikkatlice alınır.

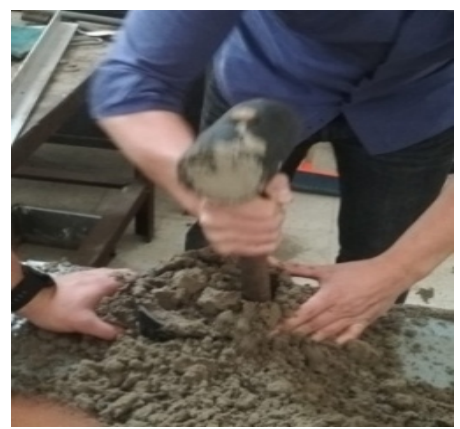

Görsel 14. Kalıba kumun sıkıştırılması

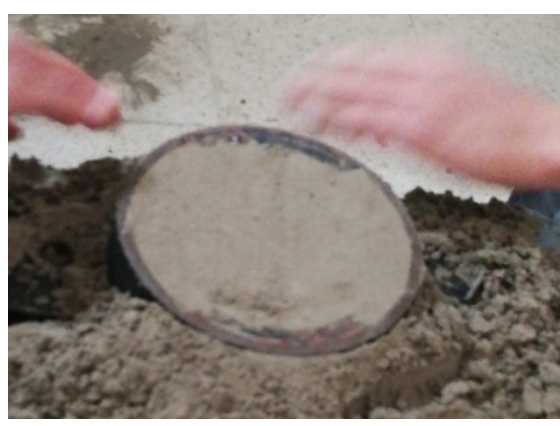

Görsel 15. Kumun kalıpla hizalanmas1

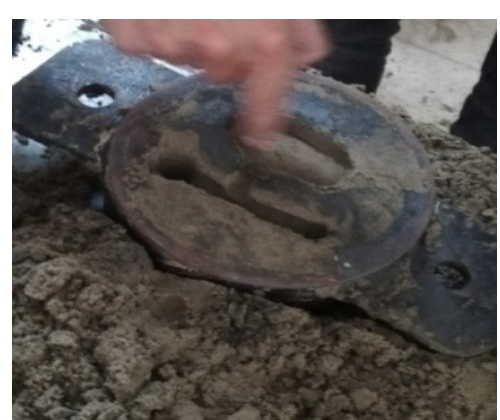

Görsel 16. Modelin kumdan çıkarılması

Modelin üst tarafına gelecek ikinci parça kalıp için grafit tozu dökülerek (Görsel 17), negatifi çıkarılan modelin üzerine demir çubuk yerleştirilip etrafı kum ile doldurularak (Görsel 18), sıkıştırma ve mastar çekme işlemleri yapilir. 


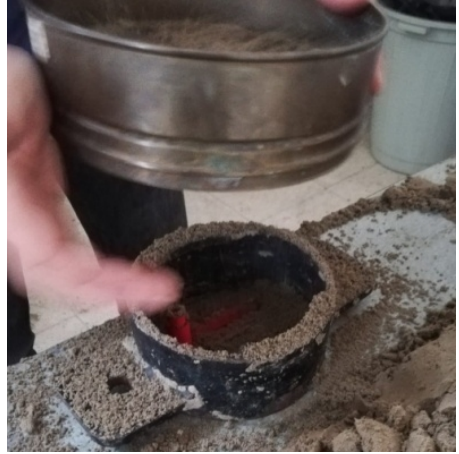

Görsel 17. Üst kalıbın hazırlanması

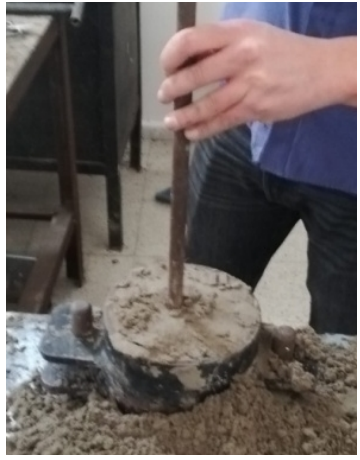

Görsel 18. Yolluk açılması

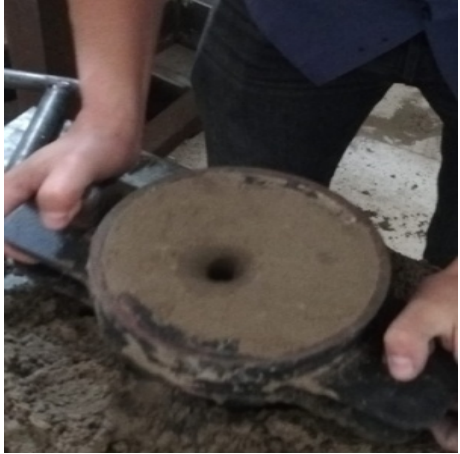

Görsel 19. Yolluğun çıkarılması

Dökümün yapılması için demir çubuk yerinden çıkarılarak (Görsel 19), ardında bıraktığı düşey yolluktan istenen hammadde dökülerek işlem tamamlanır (Görsel 20-21).

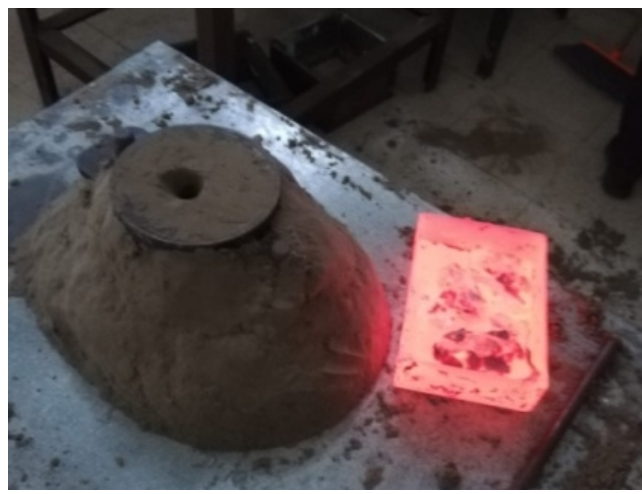

Görsel 20. Erimiș metalin kalıba dökülmesi

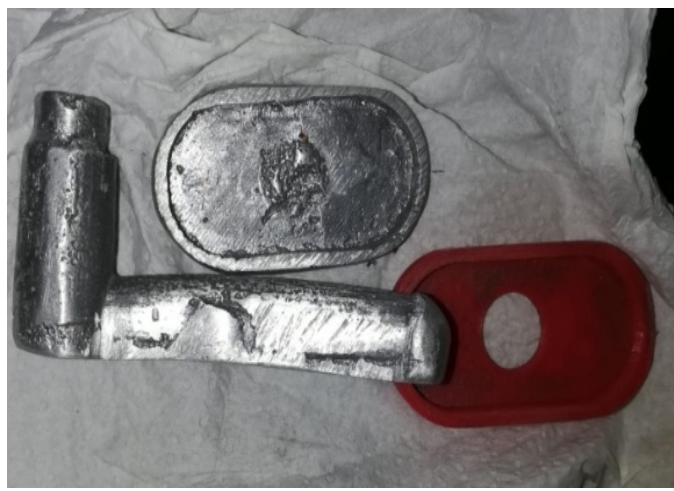

Görsel 21. İstenilen modelin elde edilmesi

$\mathrm{Bu}$ yöntem ile negatif kalıp yüzyıllardır sağlıklı bir şekilde elde edilmektedir. Ancak kum ile kalıp alma yönteminde alçı ve polyester döküm kuma yapıştığı için bu yöntem ile sadece metal döküm yapılabilmektedir. Üstelik kum döküm tekniği ile çalışmak için $1200^{\circ} \mathrm{C}$ kadar 1 sınan bir firına sahip olan atölye bulmak gerekmektedir. Kum ile kalıp alma/çıkarma yönteminin aksine Oasis ile istediğimiz her yerde kalıp alma imkânına sahip olabiliriz.

Çeşitli boy, ebat ve şekillerde temin edilebilen sünger, bu uygulamada küçük nesnelerin kalıpları alınacağı için $23 \times 11 \times 7.5 \mathrm{~cm}$ ölçülerinde tercih edilmiştir. Elde edilen bu ölçüler yan yana koyularak kalıp alınacak nesnenin ebatlarına göre bir dizilimde gerçekleştirilebilir. İstenilen dizilim tasarlandıktan sonra hazırlanan çiçek süngerinin kalıp almada kolaylık sağlaması için zeminine mukavva kesilerek hazırlanır. Tercihe ve kopyası alınacak nesnenin hacmine, boyut ve biçimine bağlı olarak, sünger kesici görevi gören misina yardımı ile ortadan ikiye ayrılarak, malzemenin çoğaltılması sağlanıp tasarruf edilebilir. Bu işlem tercih edilecekse süngerler birbirlerine sürtünerek (Görsel 22), bölünme yerlerinde misinanın bırakmış olduğu dalgalanmalar yok edilirken, süngerin birleşme çizgileri de parmakla paftalanarak (Görsel 23) yumuşak bir yüzey geçişi kazandırılır.

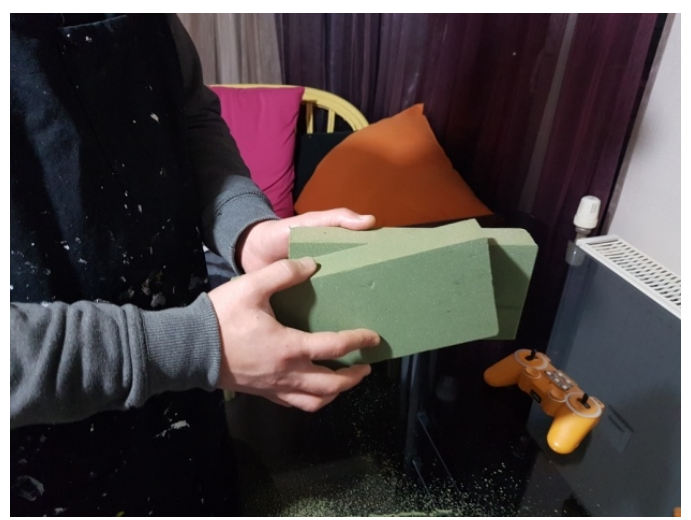

Görsel 22. Dalgalanmaların birbirine sürtünerek yok edilmesi

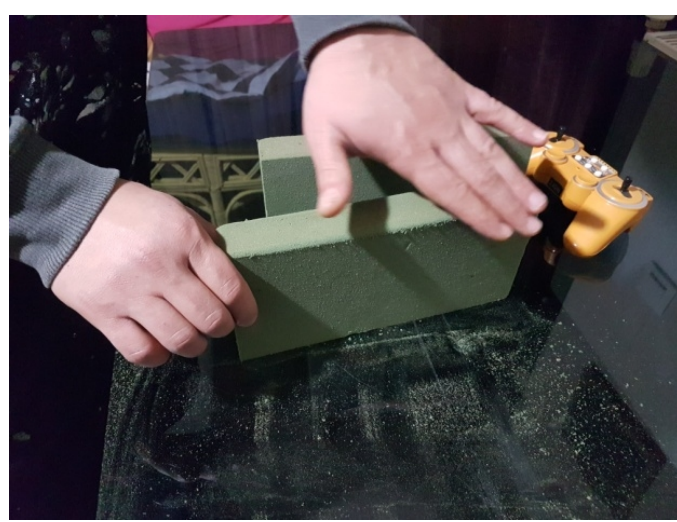

Görsel 23. Paftalama İşlemi 
Kalıbı alınacak nesnenin ebatlarına göre Oasis ve mukavva kesilerek hazır hale getirilir. Gereksinime göre kesilen süngerler şeffaf tutkal ile birleştirilerek yeniden organize edilebilir (Görsel 24 ve 25).

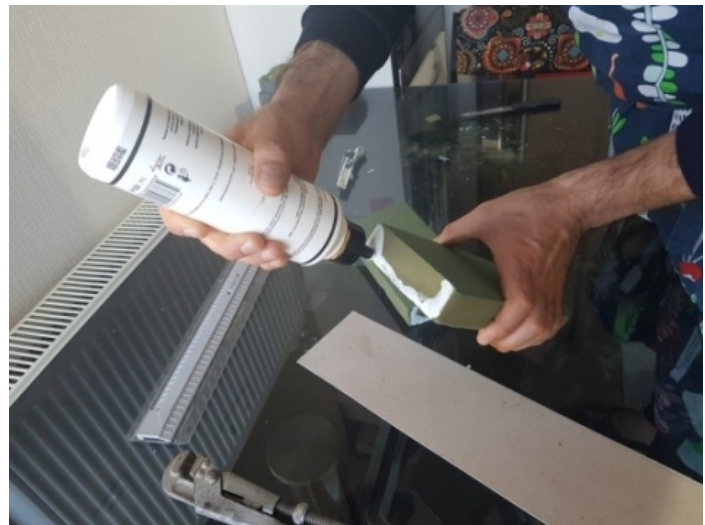

Görsel 24. Tutkallama

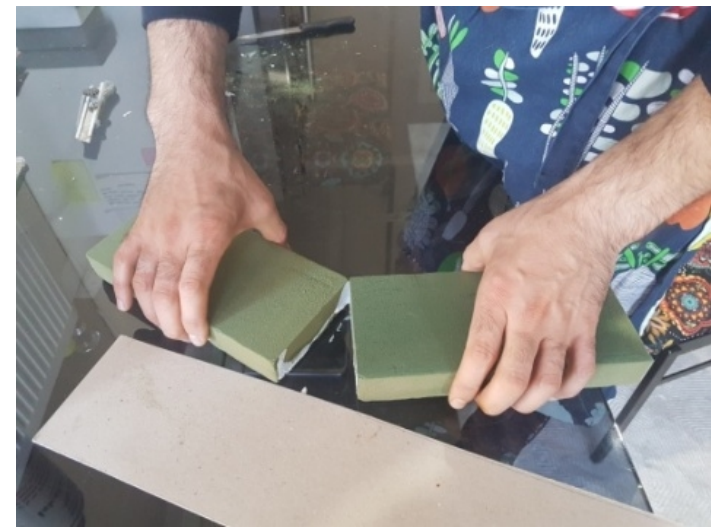

Görsel 25. Dizilime göre birleştirme

Yapılan denemeler sırasında süngerlerin birleşim yerlerinde kullanılan tutkalın fazla olması halinde sertleşip kalıbın kalitesiz olmasına neden olduğu saptanmıştır. Bu sebeple tutkal birleşme yerlerinde alt taraflara denk gelecek şekilde sürülmüştür. Kesilen mukavva, şeffaf iskelet tutkalı ile kaplanarak çiçek süngerine yapıştırılarak (Görsel 26-27) güçlendirilir. Yapılan uygulamalarda tutkal ile çiçek süngerinin birbirine sağlıklı bir biçimde yapışarak kesin sonuç vermesi için en az 8 saat bekleme süresinin yeterli olduğu saptanmıştır.

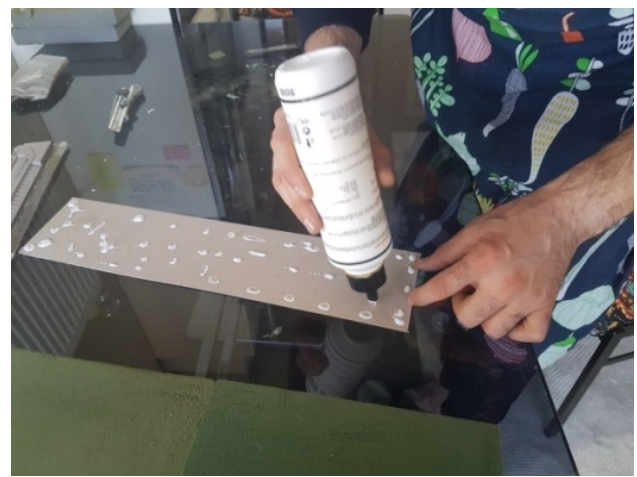

Görsel 26. Mukavvanın tutkallanması

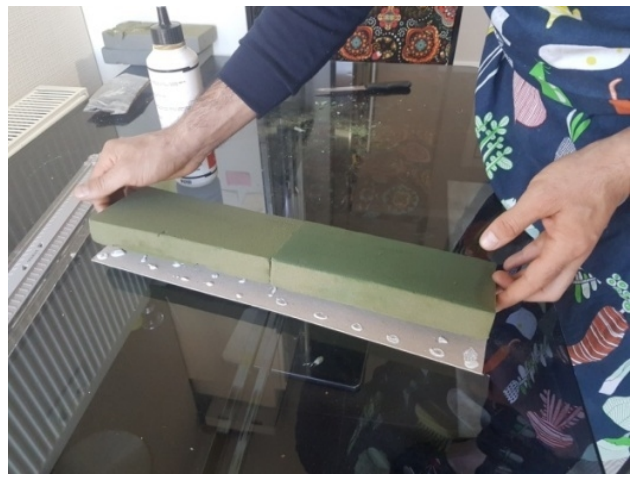

Görsel 27. Mukavvanın Oasis’e yapıştırılması

Bahsi geçen bölme, paftalama ve yapıştırma işlemleri tamamlandıktan sonra Oasis, herhangi iki ya da üç boyutlu nesnenin kalıbını almak için hazır duruma gelmiştir. Bu aşamada çoğaltılmak istenen nesne (Görsel 28), düz ve sert bir yüzey üzerine bırakılan Oasis'in üstüne dikkatlice bastırılır.

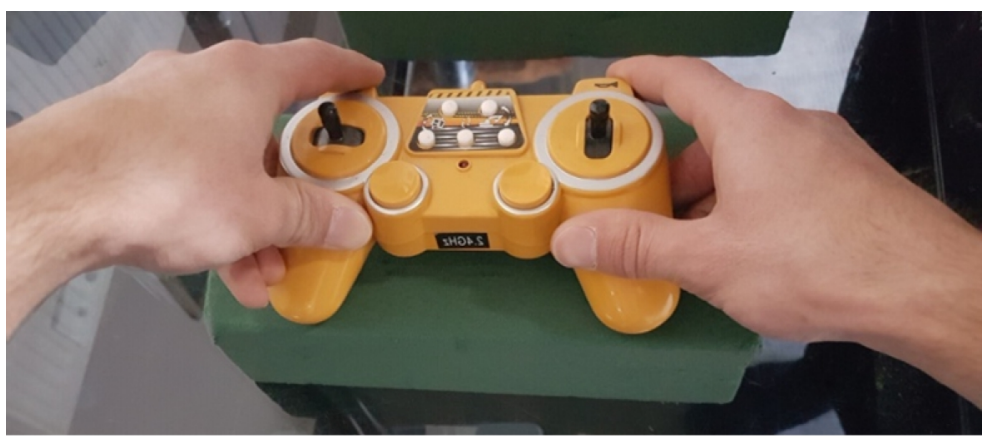

Görsel 28. I. Nesnenin Oasis’e bastırılması

Oasis'in emici ve gözenekli bir yapıya sahip olması negatif kalıplar ve nesneler için olumsuz bir etken olduğu görülmüştür. Oasis, hassas yapısı nedeni ile oldukça kırılgan ve deforme olma olasılığı çok yüksek bir malzemedir. Bu sorunu avantaja çevirmek için çeşitli malzemeler ile yapılan 60'1 aşkın denemenin sonunda Oasis'in gözenekli ve emici yapısına en çok mukavemet kazandıran malzemeler sırası ile sulu alçı, araç kaportası için kullanılan astar boya ve saç spreyi olmuştur. Bu malzemeler süngere eşit bir şekilde tutunarak malzemenin yüzeyine bir çeşit yalıtım kazandırmaktadır. 
Baskının şiddeti ile Oasis, üzerine bırakılan kütleyi içine alarak, nesnenin negatif kalıbının çıkmasını sağlar. Ardından süngerin içine gömülen iki boyutlu nesne dikkatlice çıkarılır. Elde edilen kalıpta uygulanan basınca bağlı incinen yerler var ise ahşap dolgu macunu ile müdahale edildikten sonra zımpara ile düzeltilerek, izolasyon işlemine hazır duruma getirilir. Nesnenin üç boyutlu kalıbı alınacaksa, çiçek süngerinden iki kalıp hazırlanarak, üç boyutlu nesnenin yarısı ilk kalıba dikkatlice bastırılır. Ardından hazırlanan ikinci kalıp, ilk kalıba yerleştirilen nesnenin diğer yarısını kaplayacak şekilde hizalanarak, bastırma işlemi gerçekleştirilir (Görsel 29).

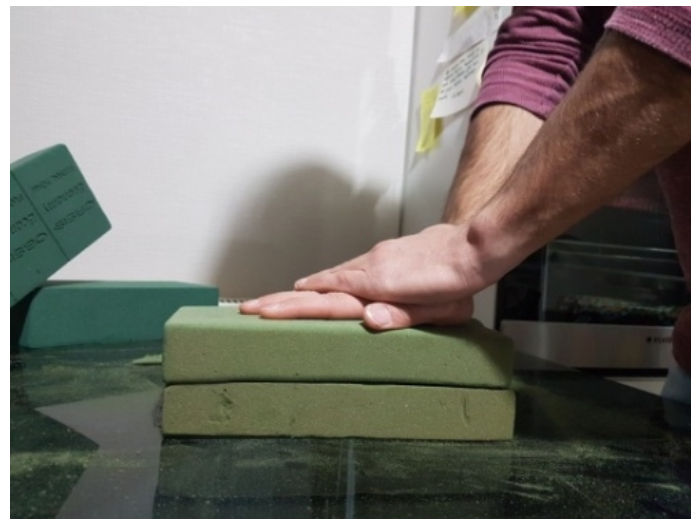

Görsel 29. I. Nesne kalıplarının birleştirilmesi

Bastırma işlemi sırasında doğru hizalama, iki kalıbın birbirleri ile öpüşmesi, dökülecek üç boyutlu nesne için çok önemlidir. Dikkatlice bastırılarak tek kalıp haline gelen iki kalıp, el yardımı ile birbirlerinden ayrılarak (Görsel 30-31) pozitif döküm için sertleştirme aşamasına geçilir. Tercihe bağlı olarak sertleştirme işlemlerinden sulu alçı, astar boya ve saç spreylerinden biri seçilir.

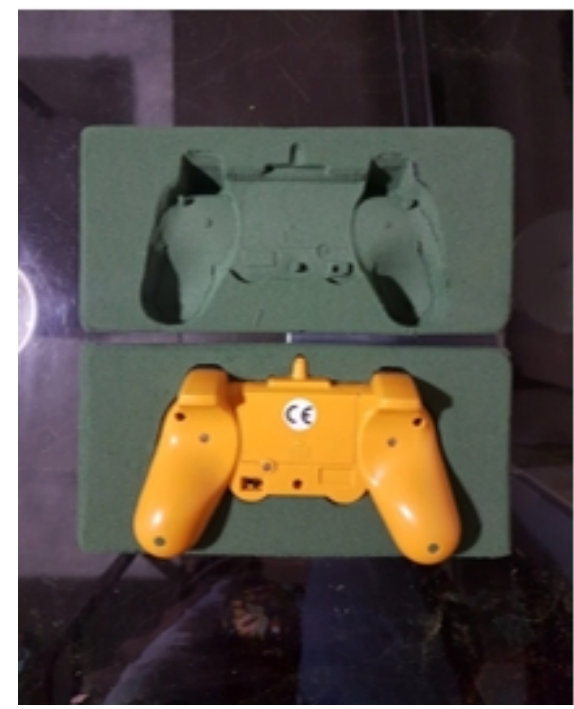

Görsel 30. I. Nesneyi kalıptan ayırma

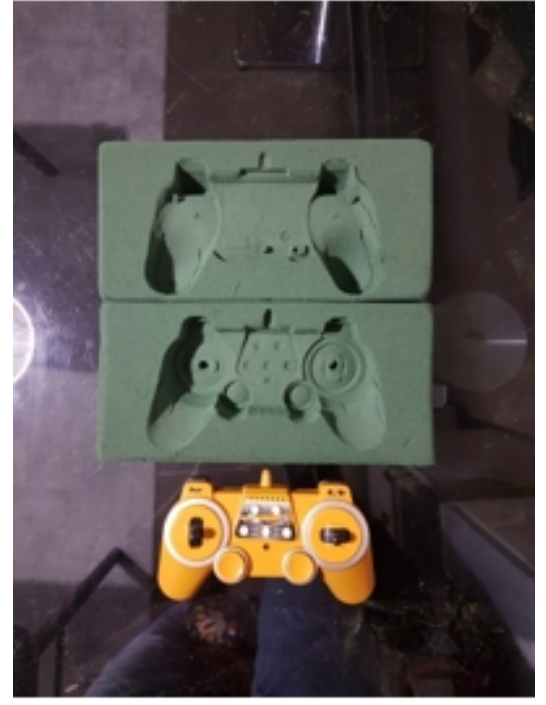

Görsel 31. I. Nesneyi kalıptan ayırma

Bu uygulamada bir tabure üzerine yerleştirilen negatif kalıp üzerinde, astar boya kullanılarak, sertleştirilmiştir. Astar boya ile nesnenin etrafında dönerek her yerinin boyanmasına özen gösterilir. Kalıbın üzerine sıkılan astar boya, yaklaşık bir saat içinde kuruyup sertleşerek, pozitif kalıp için kullanıma hazır duruma gelir. Daha önce astar boya ile yapılan uygulamalarda bu işlemin en az üç kere tekrarlanması gerektiği sonucuna varılmıştır. Bu işlemin ardından sertleşen çiçek süngeri pozitif döküm için düz bir zemine yerleştirilirken diğer yandan döküm için malzeme hazırlanır. Uygulamada döküm için maddi anlamda temin edilebilmesi kolay ve yaygın bir malzeme olan kartonpiyer alçı tercih edilmiştir.

Nesneden ayrılıp sertleşmesi sağlanan kalıplara, wax, sıvı yağ ya da sabun sürülür (Görsel 32). Daha önceki uygulamalarda bahsi geçen ayırıcıların hepsi denenmiş, içlerinde en sağlıklı sonucu wax vermiştir. 


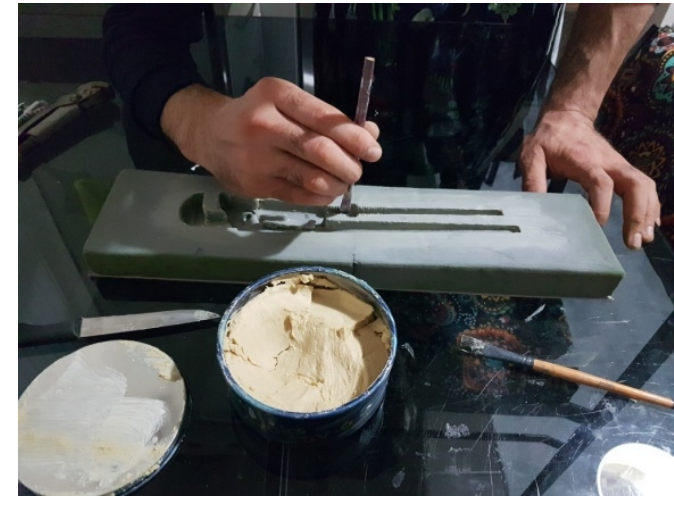

Görsel 32. II. Nesne kalıbına wax sürme

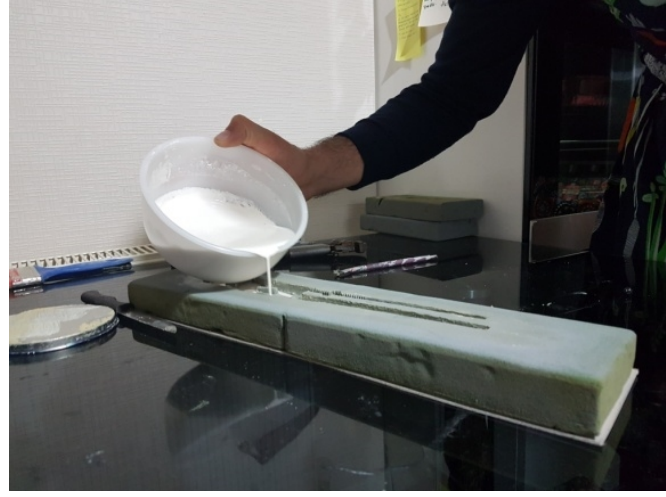

Görsel 33. II. Nesne kalıbına alçı dökme

Bu işlemin ardından hazırlanan akışkan kıvama getirilen alçı, negatif kalıpta oluşan, hacimsel dökümü yapılmak istenen nesnenin biçimini alan boşluğa, hava kabarcığı bırakmaması sağlanarak (Görsel 33) dökülür. Üç boyutlu nesne kalıbı alınacaksa kalıplar öpüştürülerek akışkan alçı, oluşturulan yoldan içeri dökülür (Görsel 34). Isınma ve soğuma işlemleri tamamlanan negatif kalıplar katılaşan nesneden dikkatlice ayrılır (Görsel 35-36).

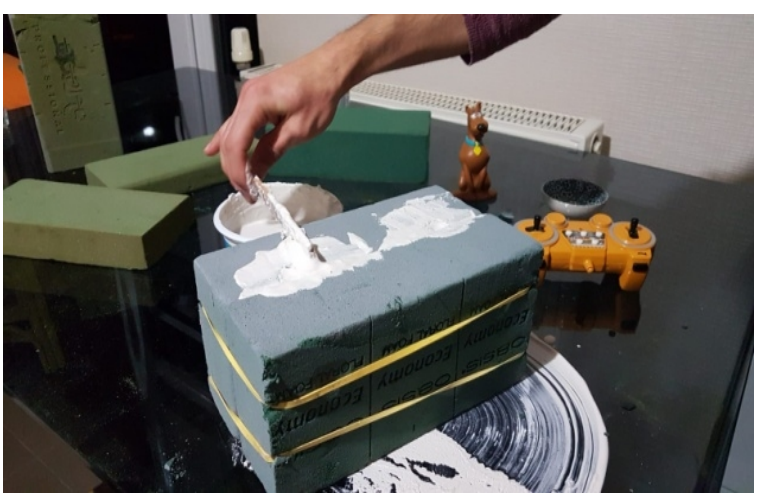

Görsel 34. I. Nesne kalıbını birleştirip düzeltme

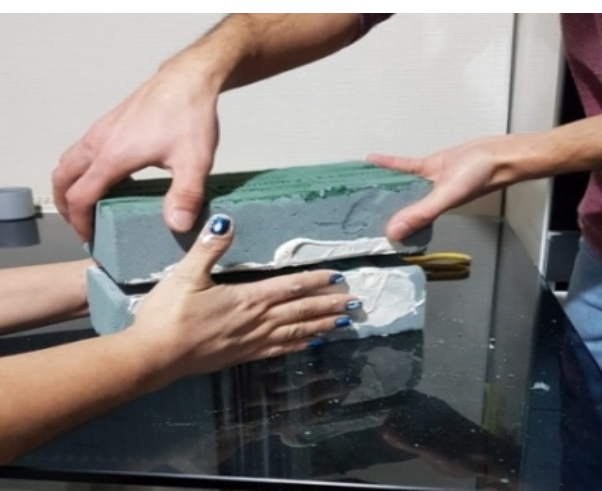

Görsel 35. I. Nesnenin alçı dökümünü kalıptan ayırma

Kalıptan çıkarılan nesne, üzerine yapışan sünger parçalarından biraz su ve bir firça yardımı ile temizlenerek ayrılır. Ardından döküm fazlalıklarından temizlendikten (Görsel 37) sonra zımparalanarak ihtiyaç halinde boyama ve patina işlemleri yapılabilir.

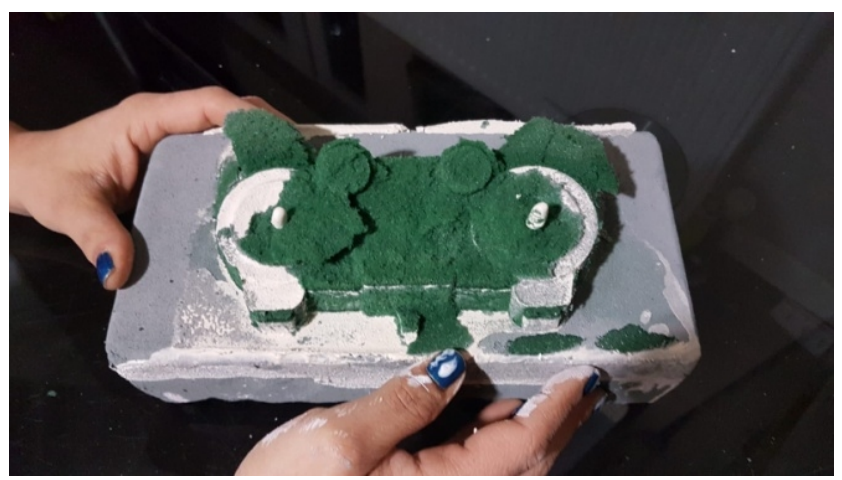

Görsel 36. I. Nesnenin alçı dökümümü kalıptan ayırma

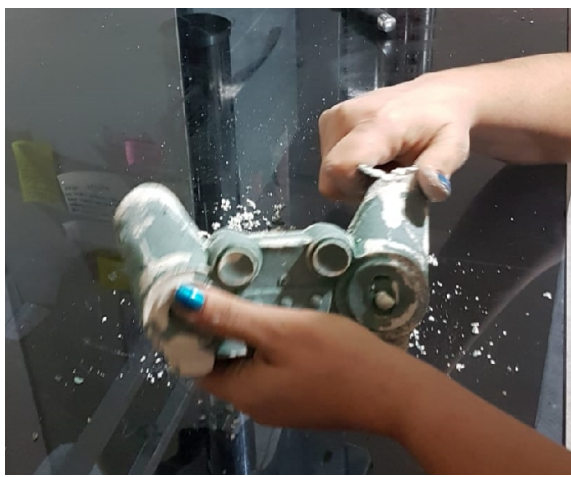

Görsel 37. I. Nesneyi tıraşlama

Kalıptan çıkarılarak fazlalıklarından temizlenen I. ve II. Nesne, orijinal nesneler ile yan yana getirildiğinde nesnenin formunun kalıp üzerine birebir işlendiği (Görsel 38 ve 39) ve aralarında herhangi bir fark olmadığ1 görülmektedir. Bu nedenle Oasis’in istenilen nesnenin kopyalarını sağlıklı bir şekilde çoğaltarak elde edebilme imkânı sağlandığını söylemek mümkündür. 


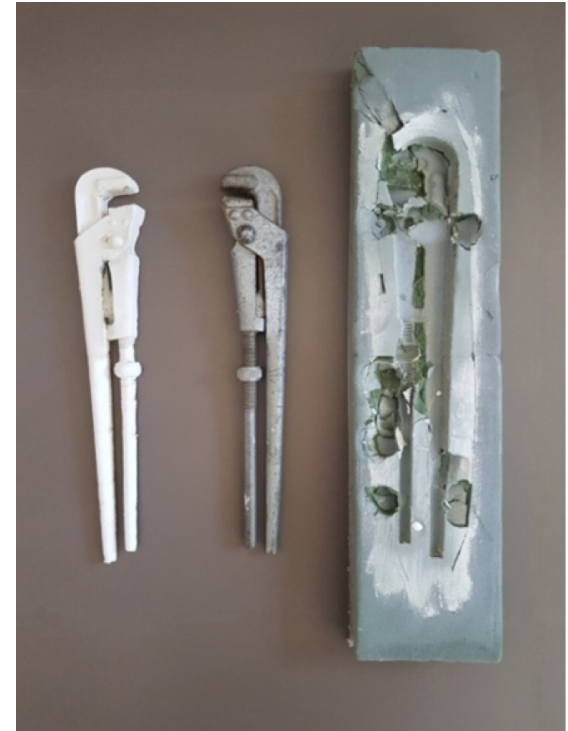

Görsel 38. II. Nesnenin kalıptan ayrılması

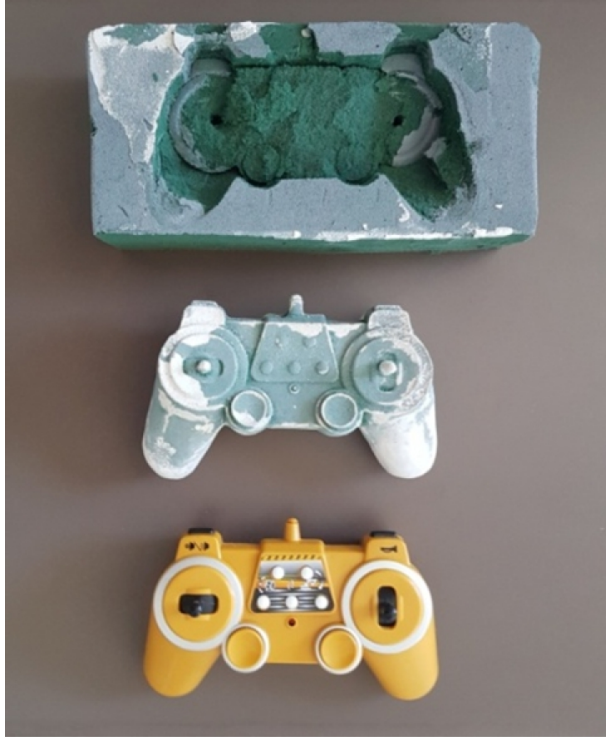

Görsel 39. I. Nesnenin kalıptan ayrılması

\section{Sonuç Yerine}

$\mathrm{Bu}$ araştırma, heykel sanatında geleneksel ve güncel kalıp alma tekniklerine ilaveten yeni bir öneri olarak temellendirilmiştir. Bu öneri doğrultusunda çeşitli uygulamalar yapılarak, yeni bilgiler elde edilmiş, üretim yöntemlerinin malzeme dağarcığına bir yenisi eklenmek istenmiştir. Yapılan uygulamada Oasis’in çeşitli nesnelerin kalıplarını alıp dökümlerini yapabilmek için uygun bir malzeme olduğu görülmüştür. Malzemenin kendi doğasından kaynaklanan hassasiyeti, kalıbı alınacak nesnenin kendisine temas edip bastırma işlemi gerçekleştirilene kadar avantajlı konumunu korumaktadır. Bu, kalıbı çıkarılmak, çoğaltılmak istenen nesnenin birebir formunu elde edebilmek için çok önemli bir özelliktir. Ancak form elde edildikten sonra bu hassasiyet, malzemenin yıpranarak hasar alması ya da kırılması ile sonuçlanmakta, bu sebeple de döküm aşamasına geçilememektedir. Kalıbı alınacak orijinal nesnenin yüzeyde formu elde edilene kadar oldukça avantaj sağlayan Oasis, döküm aşamasında gerekli olan şartları sağlayamadığı için dezavantajlı bir duruma gelmektedir. Bu sebeple Oasis üzerine, orijinal nesnenin kalıbı çıkarıldıktan sonra astar boya atılarak sertleşmesi sağlanmış, gerekli olduğu takdirde macun çekilmesi uygun görülerek döküm yapılmıştır. I. ve II. Nesnenin dökümlerinin kalıptan ayrılması sağlanmış, temizleme işlemleri yapılmıştır. Bu işlemlerin ardından I. ve II. nesne orijinal ve kopyaları ile bir araya getirilerek aralarında bir fark olmadığı gözlemlenmiştir.

Sonuç olarak Oasis'in, çeşitli ölçülerde nesnelerin kalıplarının alınması ve dökümlerinin yapılması için elverişli bir malzeme olduğu saptanmıştır. Bu bağlamda Oasis aracılığı ile elde edilen kalıp ve nesnelerin yeni bir yöntem biçimi oluşturmakla beraber, birçok yönü ile yeni arayışlara, doğaçlama ve denemelere referans olması beklenmektedir. Bu çerçevede uygulama süresince görsel ve yazılı kaynaklar raporlaştırılarak, yazıyı inceleme firsatı bulan okuyucunun evinde veya atölyesinde maliyeti yüksek olmayan, emek ve zamandan tasarruf ederek, benzer süreci tekrar etmesi amaçlanmıştır.

\section{Kaynakça}

Boardman, J. (2013). Yunan heykeli klasik dönem. (G. Ergin, Çev.). İstanbul: Homer Kitapevi ve Yayıncılık Ltd. Şti.

Bulat, M. (1999). Antik Çağ taş yontu sanatında ölçüm ve kopyalama yöntemleri. Atatürk Üniversitesi Güzel Sanatlar Fakültesi Sanat Dergisi. 1, 121-131. Erişim adresi: https://dergipark.org.tr/en/download/articlefile/28784.

Bulat, M. (2014). Modern Sanatta Soyutlama. Erzurum: Atatürk Üniversitesi Yayınları.

Bulat, M., Bulat, S., Sabahat, S., \& Aydın, B. (2014). Antik Çăgdan Günümüze Yontu ve Kopya Teknikleri. Erzurum: Atatürk Üniversitesi Yayınları.

Çelik, C. (2019). Kültür endüstrisi ve sanat ilişkisi içerisinde esin, taklit, alıntı, çalıntı (Doktora Tezi). Işık Üniversitesi Sosyal Bilimler Enstitüsü, İstanbul. Erişim adresi: https://acikerisim.isikun.edu.tr/xmlui/ handle/11729/2195?show=full\#sthash.bpUoB4Eh.dpbs. 
Hiçyılmaz, G. (2018). Heykel sanatında değişen malzeme tutumları bağlamında 1960 sonrası heykelde yumuşak malzemelerin ortaya koyduğu yeni olanaklar (Yüksek Lisans Tezi). YÖK Tez veri tabanından erişildi. (Tez No. 506599)

İba, Ş. M. (2018, Ekim). Heykel tasarımı ve yapımında çağdaş bilgisayar teknolojilerinin kullanımı. Elsander I. Uluslararası Sanat ve Tasarım Sempozyumu'nda sunulan bildiri, Antalya.

İşcanoğlu, K. (2017). Basit kömür kalem yapımı ve yeni bir medyum olarak zor silinen kömür kalem. Bartın Üniversitesi Çeşm-i Cihan: Tarih Kültür ve Sanat Araştırmaları E Dergisi. 4(2), 49-61. Erişim adresi: https://dergipark.org.tr/tr/download/article-file/383805

Kopya kelime kökeni. (t.y.). Erişim adresi: https://www.etimolojiturkce.com/kelime/kopya. Erişim Tarihi: 22.12.2019

Oasis çiçek süngeri. (t.y.). Erişim adresi: https://www.cicekmalzemeci.com/oasis-cicek-sungeri

Original sculptures and subsequent copied works. (2009, 19 Ocak). Erişim adresi: https://www.gillesperrault. com/loeuvre-originale-et-la-sculpture-dedition-2

Özkul, T. (2019). Disiplinlerarası süreç bağlamında çağdaş heykel sanatının plastik dil olarak kullanılması. Bartın Üniversitesi Çeşm-i Cihan: Tarih Kültür ve Sanat Araştırmalarl E Dergisi. 6(2), 60-72. doi:10.30804/cesmicihan.6448372

Pointing machine. (t.y.). Erişim adresi: https://www.wikiwand.com/en/Pointing_machine.

Poyraz, B., \& Dolunay, A. (2014). Heykel sanatında ön modelleme aşaması ve üç boyutlu yazıcı uygulamaları. Ulakbilge Sosyal Bilimler Dergisi. 2(3), 69-80. Erişim adresi: http://www.ulakbilge.com/makale/pdf/ 1407507129.pdf

Sağlamtimur, Z. Ö. (2010). Dijital sanat. Anadolu Üniversitesi Sosyal Bilimler Dergisi. 10(3), 213-238. Erişim adresi: https://www.academia.edu/553913/D\%C4\%B0J\%C4\%B0TAL_SANAT.

Turak, Ö. (2017). Eski Roma uygarlığı ve heykel: Yağma-koleksiyonculuk. Türkiye Bilimler Akademisi Arkeoloji Dergisi. 21, 135-145. Erişim adresi: http://tubaar.tuba.gov.tr/index.php/tubaar/article/view/350.

Türk Dil Kurumu. (t.y.). Kopyalamak. Erişim adresi: https://sozluk.gov.tr/

Yılmaz, S. (2018). Antik Çağ (Yunan-Roma) heykeltıraşlığında renk ve boya (Yüksek Lisans Seminer Çalışması). Uşak Üniversitesi Sosyal Bilimler Enstitüsü Arkeoloji Ana Bilim Dalı, Uşak.

\section{Görsel Kaynakça}

Görsel 1. Noktalama aleti. Erişim adresi: http://blog.stephens.edu/arh101glossary/wp-content/uploads/2016/07/ pointing-machine.png

Görsel 2. Değişik noktalama yerlerini işaretleyebilmek için ayaklı pergelin kullanım (Alex Miller). Bulat ve diğerleri. (2014). Antik doğadan günümüze yontu ve kopya teknikleri. Erzurum: Atatürk Üniversitesi Yayınları.

Görsel 3. Ahşap çerçeve metodu ile kopyalama yöntemi. Erişim adresi: https://www.didatticarte.it/Blog/?p= 3904.it

Görsel 4. Ahşap çerçeve ve şakülle heykel üzerinde ölçümleme yapma işlemi. Erişim adresi: https://arteraccontataneilibri.blogspot.com/2018/06/antonio-canova-e-la-bellezza-ideale.html.

Görsel 5. Kalipper aleti ile modelden taş blok üzerine ölçümleme. Bulat ve diğerleri. (2014). Antik doğadan günümüze yontu ve kopya teknikleri. Erzurum: Atatürk Üniversitesi Yayınları.

Görsel 6 ve 7. Olympia Zeus tapınağında bulunan aslan başı. Berlin Bergama Müzesi, İ.Ö.460. Erişim adresi: https://www.google.com/search?q=lion+head+zeus+temple\&tbm

Görsel 8. 3 Boyutlu Yazıcı. Erişim adresi: http://soliddizayn.com/galeri_m/HEYKEL-ISLEME\%7C4310

Görsel 9. Cnc Makinesi. Erişim adresi: https://www.hepsiburada.com/toprak-renkli-3-boyutlu-yazici-3db9diamond-3d-printer-pm-HB00000D6IL2

Görsel 10. Oasis (Çiçek süngeri). Erişim adresi: https://urun.n11.com/ambalaj-malzemeleri/oasis-cicek-sungeri20-li-P289024871

Görsel 11. Kumun karılması. Ömer Karaduman arşivinden alınmıştır.

Görsel 12. İki parçadan oluşan kalıp. Ömer Karaduman arşivinden alınmıştır. 
Görsel 13. Kumun elenmesi. Ömer Karaduman arşivinden alınmıştır.

Görsel 14. Kalıba kumun Sıkıştırılması. Ömer Karaduman arşivinden alınmıştır.

Görsel 15. Kumun kalıpla hizalanması. Ömer Karaduman arşivinden alınmıştır.

Görsel 16. Modelin kumdan çıkarılması. Ömer Karaduman arşivinden alınmıştır.

Görsel 17. Üst kalıbın hazırlanması. Ömer Karaduman arşivinden alınmıştır.

Görsel 18. Yolluk açılması. Ömer Karaduman arşivinden alınmıştır.

Görsel 19. Yolluğun çıkarılması. Ömer Karaduman arşivinden alınmıştır.

Görsel 20. Erimiş metalin kalıba dökülmesi. Ömer Karaduman arşivinden alınmıştır.

Görsel 21. İstenilen modelin elde edilmesi. Ömer Karaduman arşivinden alınmıştır.

Görsel 22. Dalgalanmaların birbirine sürtünerek yok edilmesi. Tülay Özkul kişisel arşivi.

Görsel 23. Paftalama İşlemi. Tülay Özkul kişisel arşivi.

Görsel 24. Tutkallama. Tülay Özkul kişisel arşivi.

Görsel 25. Dizilime göre birleştirme. Tülay Özkul kişisel arşivi.

Görsel 26. Mukavvanın tutkallanması. Tülay Özkul kişisel arşivi.

Görsel 27. Mukavvanın Oasis’e yapıştırılması. Tülay Özkul kişisel arşivi.

Görsel 28. I. Nesnenin Oasis'e bastırılması. Tülay Özkul kişisel arşivi.

Görsel 29. I. Nesne kalıplarının birleştirilmesi. Tülay Özkul kişisel arşivi.

Görsel 30. I. Nesneyi kalıptan ayırma. Tülay Özkul kişisel arşivi.

Görsel 31. I. Nesneyi kalıptan ayırma. Tülay Özkul kişisel arşivi.

Görsel 32. II. Nesne kalıbına wax sürme. Tülay Özkul kişisel arşivi.

Görsel 33. II. Nesne kalıbına alçı dökme. Tülay Özkul kişisel arşivi.

Görsel 34. I. Nesne kalıbını birleştirip düzeltme. Tülay Özkul kişisel arşivi.

Görsel 35. I. Nesnenin alçı dökümünü kalıptan ayırma. Tülay Özkul kişisel arşivi.

Görsel 36. I. Nesnenin alçı dökümümü kalıptan ayırma. Tülay Özkul kişisel arşivi.

Görsel 37. I. Nesneyi tıraşlama. Tülay Özkul kişisel arşivi.

Görsel 38. II. Nesnenin kalıptan ayrılması. Tülay Özkul kişisel arşivi.

Görsel 39. I. Nesnenin kalıptan ayrılması. Tülay Özkul kişisel arşivi. 